Dept. of Poultry Diseases,

Faculty of Vet. Med., Assiut Univ., Assiut-Egypt

\title{
ASSOCIATED PROFILES OF VIRULENCE GENE MARKERS IN CLOSTRIDIUM PERFRINGENS STRAINS ISOLATED FROM HEALTHY AND DISEASED BROILER CHICKENS WITH NECROTIC ENTERITIS
}

(With 3 Tables and 4 Figures)

By

\section{M.A. MOHAMED; SYLVIA O. AHMED*} and T.Y. ABDEL MOTELIB

* Dept. Animal Hygiene and Zoonosis, Fac.of Vet. Med., Assiut University, Assiut, Egypt.

(Received at 12/9/2009)

البروفيل المصاحب لدلالات جينات الضرواة لعترات الكلوستيريديم بيرفيرنجينز

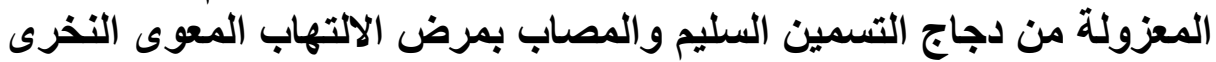

مؤمن عبد العظيم محدد ، سيلفيا أسامة أحمد ، طلبة بيونس عبد المطلب

تعتبر الكلوستيريديم بيرفيرنجينز المسبية لمرض الالتهاب المعوى النخرى من المخاطر

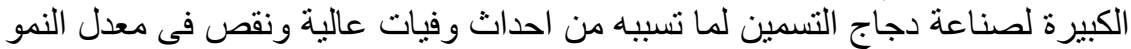

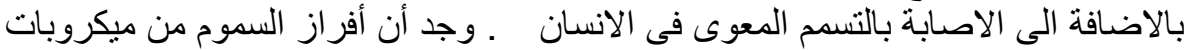

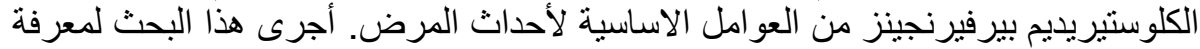

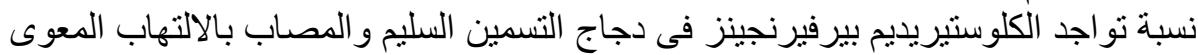

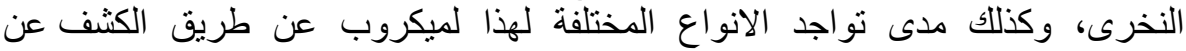

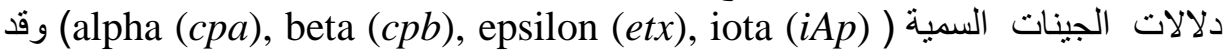

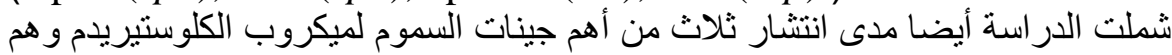
(cpe, cpb2 and netB)

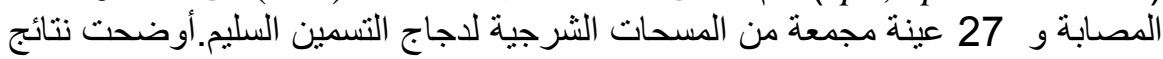

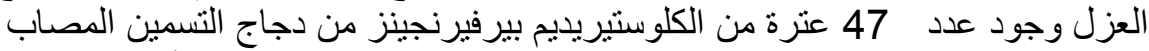

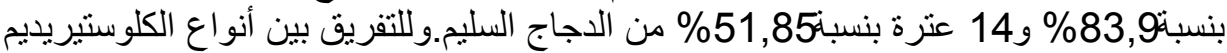

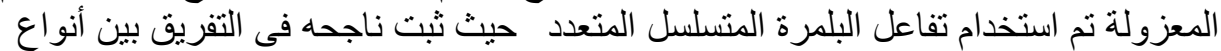

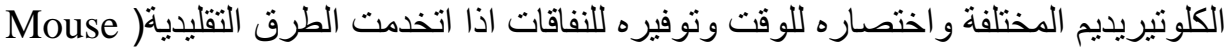
Toxin Neuratlization Test

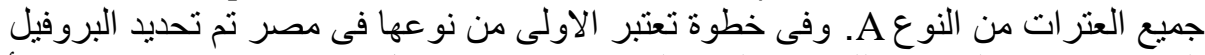

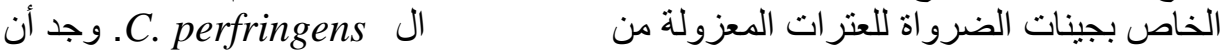
البروفيل الجينى بالنسبة لجين التسمم المعوى cpe هو عدم امتلاك اى من العترات المصاحبة 


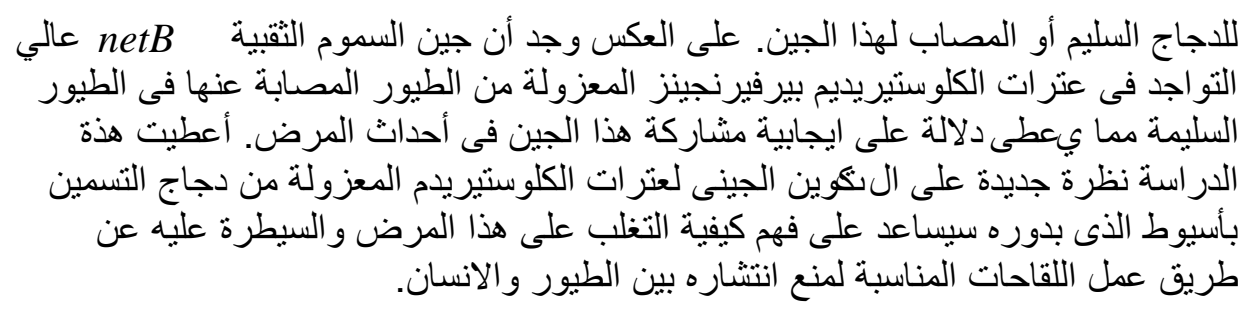

\section{SUMMARY}

Clostridium perfringens induced necrotic enteritis (NE) and subclinical disease have become important threats to poultry health and is one of the main causes of losses in broiler flocks due to high mortalities and reduction in growth rate as well as enterotoxemias in domestic animals and humans . The mechanism of virulence of $C$. perfringens, a bacterium causing necrotic enteritis in birds, results largely from its ability to produce toxins. A study was set up to look the rate of carriage of $C$. perfringens among broilers with different heath status, incidence rate of the different toxin genotypes of $C$. perfringens in healthy and diseased birds and, lastly, the relative abundance of $c p e, c p b 2$ and net $B$ virulence genes. Broiler chickens from healthy flocks were sampled by cloacal swabs, while intestinal and liver samples of birds suffering from necrotic enteritis were analysed. A total of $47(83.9 \%)$ isolates was obtained from 56 examined pooled samples $(n=4)$ of broiler chickens with clinical problems and $14(51.85 \%)$ isolates were obtained from 27 pooled samples $(n=4)$ from broiler chickens without clinical problems. Seroneutralization with mice or guinea pigs has been used to type each toxin, but this conventional method has some disadvantages. Therefore, we used a multiplex PCR (m-PCR) assay with primers amplifying fragments of alpha (cpa), beta (cpb), epsilon (etx), iota (iap), for genotyping of isolated $C$. perfringens strains. All 61 broiler chicken C. perfringens isolates were shown to carry the cpa gene but not $c p b$, etx and $i A$ genes, signifying that all isolates represented type A. For the first time the associated profiles of the following virulence genes [ cpe, $c p b 2$ (beta-2 toxin) and the newly described pore forming toxin gene (netB)] were determined among Egyptian isolated $C$. perfringens strains. None of the isolates contained the enterotoxin gene that may indicate the enterotoxin of $C$. perfringens does not play important role in the occurrence of Necrotic enteritis in broiler chickens. netB was almost always found in outbreak isolates, suggesting a positive correlation of $n e t B$ toxin gene with the diseased status that may explain its role in the pathogenesis of the disease. Whereas $c p b 2$ was found in healthy and 
diseased bird isolates that suggest there is a weak or no relationship between beta 2 toxin and necrotic enteritis in birds. So this study throw novel insights into the presence and distribution of $C$. perfringens types as well as virulence-associated genes in field strains, which will help us to understand the pathogenesis of disease in poultry and more comprehensively characterize $C$. perfringens in future studies to put a suitable strategy for prevention and control.

Key words: Clostridium perferingens, broiler chickens, virulence and m-PCR.

\section{INTRODUCTION}

Enteric diseases are an important concern to the poultry industry because of lost productivity, increased mortality, reduced welfare of birds and the associated contamination of poultry products for human consumption (Dahyia et al., 2006).

One of the most important enteric diseases that affected broilers is necrotic enteritis (NE). NE was first described by Parish in 1961 (Parish, 1961), and since then it has been reported to occur in almost all poultry-producing countries. NE in chickens gets in two forms, as an acute or chronic enterotoxemia (Van Immerseel et al., 2004). The acute disease results in significant levels of mortality whereas the chronic disease leads to loss of productivity and welfare concerns. It has been estimated that the disease costs the international poultry industry in excess of \$US 2 billion per year based on average damage of $\$ 0.05$ per bird (McReynolds et al., 2004).

$\mathrm{NE}$ is an enteric disease that is caused predominantly by Clostridium perfringens type A and to a lesser extent by type $\mathrm{C}$ strains (Songer, 1996). Mucosal damage inducing factors such as coccidiosis (parasitism), high fiber litters, dietary changes, poor hygienic and housing conditions are considered predisposing factors for NE. The NE is thought to occur when these factors create a favorable environment for $C$. perfringens to multiply rapidly into much higher numbers in the small intestine, leading to the production of potent lethal toxins that damage the intestine. Moreover, excessive uses of growth promoting antibiotics enhance $C$. perfringens to induce $\mathrm{NE}$ and sub clinical infections, important threats to poultry health (Songer, 1996).

$C$. perfringens in poultry constitutes a risk for transmission to humans through the food chain. $C$. perfringens is one of the most frequently isolated bacterial pathogens in foodborne disease outbreaks in humans, after some other pathogens such as Campylobacter and Salmonella (Buzby and Roberts, 1997). 
The pathogenicity of the organism is associated with several toxins which are used for toxin typing of the bacteria. The alpha $(\alpha)$, beta $(\beta)$, iota (l) and epsilon ( $\varepsilon$ ) are the major lethal toxins produced by the organism that are closely related to its virulence (Petit et al., 1999). $\alpha$-toxin (phospholipase $\mathrm{C}$ ) is commonly produced by all 5 types. It can hydrolyze lecithin into phosphorylcholine and diglyceride, which leads to tissue damage. $\beta$-toxin is produced by $C$. perfringens type $\mathrm{b}$ and type $\mathrm{C}$ strains and it causes a necrotic enteritis characterized by haemorrhagic mucosal ulceration or superficial mucosal necrosis of the small intestine in animals (types B and C) (Smedley III et al., 2004).

Clostridium perfringens is classified into five types (A-E) on the basis of their ability to produce major lethal toxins. Within these five types, all $C$. perfringens produce $\alpha$ toxin. In addition, type B strains produce $\beta$ and $\varepsilon$ toxins, type $C$ produces $\beta$ toxin, type $D$ produces $\varepsilon$ toxin and type $\mathrm{E}$ produces 1 toxin. In addition to the major lethal toxins, a minority of $C$. perfringens strains produce a $C$. perfringens enterotoxin (CPE), which is responsible for the symptoms of common $C$. perfringens type A food poisoning. Different meats, including poultry meat, have been frequently reported as the most common food vehicles (Eisgruber and Hauner 2001; McClane 2001).

The classification of $C$. perfringens isolates into toxigenic types has been traditionally performed by toxin neutralization test in mice. This procedure consumes a lot of antisera and experimental animals. Additionally it is time consuming. Nowadays, with the advent of highly efficient detection chemistries, sensitive instrumentation and optimized assays the number molecular techniques such as polymerase chain reaction (PCR) have been used to type $C$. perfringens (Gkiourtzidis et al., 2001; Baums et al., 2004; Gholamiandekhordi et al., 2006) according to the presence of toxin genes.

The virulence factors which lead to the development of NE have yet to be fully understood. Based on experimental studies, early investigators suggested that alpha toxin is the major toxin involved in causing NE (Fukata et al., 1988), and there are recent reports that vaccination against alpha toxin is at least partially protective against the disease (Lovland et al., 2004; Copper et al., 2009). However, Keyburn et al. (2006) have reported that alpha toxin knockout mutants of C. perfringens were able to produce necrotic enteritis in an experimental model.

Keyburn et al. (2008) reported the discovery of pore forming toxin of $C$. perfringens which they named NetB. netB gene was only 
identified in strains recovered from chickens with $\mathrm{NE}$ and not found in isolates from chickens which did not have NE. Keyburn et al. (2008) also mentioned that netB knockout mutants failed to produce NE in chickens, while such mutants complemented with the wild type netB gene did cause NE. Clearly, the identification of the toxin responsible for NE would represent a major advance in knowledge, so there remains a need to examine isolates from other countries like Egypt for the presence of $n e t B$.

Prophylaxis and control of necrotic enteritis is essential in broiler flocks, and the primary approach to this has been vaccination. For this to be successful, the vaccine must be based upon strains which are clinically relevant. Thus, identification of $C$. perfringens toxinotypes using a robust genetic test for the presence of toxin-encoding genes is critical for both epidemiological studies and for development and effective use of preventative measures, including vaccination.

However, there are no published data on molecular typing of C. perfringens in broilers in Assiut, Egypt. So, we report here for the first time in Egypt esp. in Assiut and Upper Egypt, testing of a multiplex polymerase chain reaction (PCR) assay for the simultaneous identification of the $C$. perfringens toxin genotyping as well as molecular analysis of the virulence genes among this pathogen and the its association with the disease to undertake the development of control measures, especially for the formulation of cost effecting vaccine.

\section{MATERIALS and METHODS}

\section{History of broiler chickens and sample collection:}

Cases of enteric disorders compatible with necrotic enteritis in 21 to 32 days old broiler chickens reared in different poultry farms in Assiut province, Egypt occurred in the months of September 2009 to Novemeber 2009 were investigated. These farms previously exposed to enteric infection, mainly with coccidiosis.

A daily mortality rate of 1.5 to $2 \%$ was recorded. The mortality peak was terminated by a 3-5 day antibiotic treatment with amoxicillin. In every case, postmortem was performed as soon as possible after death. All the internal organs were thoroughly examined and any macroscopic and gross lesions observed were recorded.

Intestinal contents esp. duodenum $(n=168)$ and gall bladder of affected liver samples $(n=56)$ from diseased birds as well as 108 samples 
of cloacal swabs from healthy birds were collected for microbiological investigation.

\section{Culture of $C$. perfringens}

Pool samples $(n=4)$ were inoculated in sterile cooked meat medium broth (Difco), then overlaid with mineral oil and incubated at $37^{\circ} \mathrm{C}$ for $24 \mathrm{hr}$.

The inoculums from each cooked meat broth media were seeded onto 5\% citrated sheep blood agar containing $12 \mathrm{mg}$ kanamycin sulphate and 30,000 U polymyxin B sulphate/Liter then incubated anaerobically with an anaerobic gas-pack system (BBL Microbiology Systems Cockeysville, Md.; Div. Becton Dickinson and Co.) for $48 \mathrm{hr}$ at $37^{\circ} \mathrm{C}$. Pure colonies were obtained by plating subcultures on Brucella agar and incubating them anaerobically for 24 hours.

The identity of isolates was confirmed by bacterial colonies characteristics (size, shape, color and patterns of haemolysis on blood agar produced a double zone of hemolysis), motility test, Gram's and malachite spore staining, litmus milk test, gelatinase, lecithinase and fermentation of glucose and lactose (Holt et al., 1994).

Detection of Clostridium perferingens types by Multiplex PCR of toxin genes:

\section{DNA extraction}

A liquots $(300 \mathrm{uL})$ of stored culture suspensions were transferred to microfuge tubes, boiled for $10 \mathrm{~min}$ in a low power microwave, centrifuged at 13,000 xg for $5 \mathrm{~min}$ (Ferrarezi et al., 2008), and DNA precipitated with $1 \mathrm{~mL}$ absolute ethanol for $3 \mathrm{~h}$ at $-60 \mathrm{C}$. After centrifugation, pellets were dissolved in $50 \mathrm{uL}$ ultrapure water (Ultra Pure DistilledWater, Invitrogen) and incubated at 56C for $20 \mathrm{~min}$. An aliquot $(5 \mathrm{uL})$ of this extracted DNA was used as template in PCR genotyping.

\section{Multiplex PCR assay}

Two multiplex PCR were used: one for detection of $c p a, c p b 1$, cpetx, and cpi genes and one for detection of cpb2, cpe and netB genes. PCR Primers, and references to the sequences from which they were derived, are presented in Table 1.

The multiplex PCR assay was performed by a modification of a previously described method (Songer and Bueschel, 1999). Briefly, each $50 \mathrm{uL}$ reaction contained $25 \mu \mathrm{l} 2 \times$ QIAGEN Multiplex PCR Kit (Qiagen) containing HotStart Taq polymerase, multiplex PCR buffer, dNTP mix and $3 \mathrm{mM} \mathrm{MgCl} 2$, a final concentration of $0.4 \mu \mathrm{M}$ for each primer 
(1 $\mu \mathrm{l}$ of each primer), $8 \mu \mathrm{l}$ sterile RNase-free water and $5 \mu \mathrm{l}$ of test or control DNA.

Amplification was carried out in a Techne Cyclogene Thermocycler, using a program composed of $5 \mathrm{~min}$ at $94^{\circ} \mathrm{C}, 35$ cycles consisting of $1 \mathrm{~min}$ at $94^{\circ} \mathrm{C}$ as initial denaturation, $1 \mathrm{~min}$ at $55^{\circ} \mathrm{C}$, and 1 min at $70^{\circ} \mathrm{C}$ ), and a final incubation for $10 \mathrm{~min}$ at $72^{\circ} \mathrm{C}$ as final elongation cycle. Negative (ultrapure water) controls were included. PCR products were examined by electrophoresis in a $1.2 \%$ agarose gel with $5 \mu \mathrm{L} / 100 \mathrm{~mL}$ of ethidium bromide and visualized by UV transillumination, then documented with a gel documentation system (BioRad, Munich, Germany). Molecular weight marker (1 kb Plus DNA Ladder) was added to agarose gels before electrophoresis.

Table 1: Target toxin gene, oligonucleotide primer sequences and length of amplification products of the $C$. perfringens multiplex PCR.

\begin{tabular}{|c|c|c|c|c|}
\hline $\begin{array}{l}\text { Primers of } \\
\text { toxin gene }\end{array}$ & $\begin{array}{r}\text { Amplicon } \\
\text { Size (bp) } \\
\end{array}$ & Nucleotide sequence(5-3) & Referance & $\begin{array}{l}\text { Types of } C . \\
\text { perferingens }\end{array}$ \\
\hline $\begin{array}{c}c p a \\
(\alpha \text { toxin) }\end{array}$ & 900 & $\begin{array}{l}\text { AGTCTACGCTTGGGATGGAA } \\
\text { TTTCCTGGGTTGTCCATTTC }\end{array}$ & $\begin{array}{c}\text { Songer and } \\
\text { Bueschel, } 1999 \\
\end{array}$ & $\begin{array}{c}{ }^{\mathrm{a}} \mathrm{A}, \mathrm{B}, \mathrm{C}, \mathrm{D} \\
\text { and } \mathrm{E}\end{array}$ \\
\hline $\begin{array}{c}c p b \\
(\beta \text { toxin }) \\
\end{array}$ & 611 & $\begin{array}{l}\text { TCCTTTCTTGAGGGAGGATAAA } \\
\text { TGAACCTCCTATTTTGTATCCCA }\end{array}$ & $\begin{array}{c}\text { Songer and } \\
\text { Bueschel, } 1999\end{array}$ & $\mathrm{~B}$ and $\mathrm{C}$ \\
\hline $\begin{array}{c}e t x \\
\text { ( } \varepsilon \text { toxin) } \\
\end{array}$ & 396 & $\begin{array}{c}\text { TGGGAACTTCGATACAAGCA } \\
\text { TTAACTCATCTCCCATAACTGCAC }\end{array}$ & $\begin{array}{c}\text { Songer and } \\
\text { Bueschel, } 1999 \\
\end{array}$ & $B$ and D \\
\hline $\begin{array}{c}\text { iap } \\
\text { (1 toxin) }\end{array}$ & 293 & $\begin{array}{l}\text { AAACGCATTAAAGCTCACACC } \\
\text { CTGCATAACCTGGAATGGCT }\end{array}$ & $\begin{array}{c}\text { Songer and } \\
\text { Bueschel, } 1999\end{array}$ & $\mathrm{E}$ \\
\hline $\begin{array}{c}\text { cpe } \\
\text { (Enterotoxin) }\end{array}$ & 506 & $\begin{array}{l}\text { GGGGAACCCTCAGTAGTTTCA } \\
\text { ACCAGCTGGATTTGAGTTTAATG }\end{array}$ & $\begin{array}{c}\text { Songer and } \\
\text { Bueschel, } 1999\end{array}$ & Untyped \\
\hline $\begin{array}{c}c p b 2 \\
\text { (B2 toxin) }\end{array}$ & 200 & $\begin{array}{l}\text { CAAGCAATTGGGGGAGTTTA } \\
\text { GCAGAATCAGGATTTTGACCA }\end{array}$ & $\begin{array}{c}\text { Songer and } \\
\text { Bueschel, } 1999\end{array}$ & Untyped \\
\hline $\begin{array}{c}\text { net } B \\
\text { (Toxin B) }\end{array}$ & 670 & $\begin{array}{l}\text { TAATTAGTACAAGCCTTTTTTC } \\
\text { TATTACAGATTCTTTAGCATTT }\end{array}$ & $\begin{array}{l}\text { Designed in this } \\
\text { Study } \\
\text { from the } C \text {. } \\
\text { perfringens toxin } \\
\text { type A sequence } \\
\text { of } n e t B \\
\text { (EU143239.1) } \\
\text { supplied by } \\
\text { Keyburn } \text { et al., } \\
2008\end{array}$ & Untyped \\
\hline
\end{tabular}

${ }^{\mathrm{a}}$ Definition of Clostridium genotype is based upon amplification of a toxin gene fragment. Type A has $c p a$ alone, type B has $c p a, c p b$, and $e t x$, type $\mathrm{C}$ has $c p a$ and $c p b$, type D has cpa and etx, and type E has cpa and $i \mathrm{~A}$. 


\section{Clinical signs and postmortem lesions}

During appearance of necrotic enteritis, broiler chickens showed severe depression, decreased appetite, ruffled feathers and diarrhea tinged with blood prior to death. Post mortem examination showed that birds were dehydrated, mid-small intestine (Fig. 1), where the enteric mucosa was abnormally thickened like yellow brownish diphtheritic membrane (Fig. 1), and varying degrees of haemorrhages. Focal necrosis and hemorrhages on the liver surface was also noticed in some chickens. Rest other organs appeared apparently healthy.

\section{Culture of Clostridium perfringens}

A total of 56 pooled samples $(n=4)$ from diseased birds (42 intestinal pooled samples and 14 gall bladder of affected liver samples) were examined for the presence of $C$. perfringens. 47 (83.9\%) isolates of $C$. perfringens out of 56 examined pooled samples were isolated and identified by colonies characteristics on blood agar as shown in fig. 2 as well as biochemical tests as described in Bergey's manual (Holt et al., 1994) like positive fermentation of glucose, lactose, sucrose, and maltose; hydrolysis of gelatin; production of lecithinase.

Bacteriological investigation was carried out also on 27 pooled samples of cloacal swabs from healthy birds for the presence of C. perfringens, $14(51.85 \%)$ C. perfringens strains were isolated and identified (Table 2).

Table 2: Number of positive samples for $C$. perfringens isolates examined from broiler chickens.

\begin{tabular}{|c|c|c|c|c|}
\hline $\begin{array}{l}\text { Condition of } \\
\text { birds }\end{array}$ & $\begin{array}{c}\text { Small } \\
\text { intestine }\end{array}$ & $\begin{array}{c}\text { Liver } \\
\text { (gall bladder) }\end{array}$ & $\begin{array}{l}\text { Cloacal } \\
\text { swabs }\end{array}$ & Total \\
\hline Diseased birds & $42^{\mathrm{a}}\left(41^{\mathrm{b}}\right)$ & $14^{\mathrm{a}}\left(6^{\mathrm{b}}\right)$ & $-\mathrm{c}$ & $56^{\mathrm{a}}\left(47^{\mathrm{b}}\right)$ \\
\hline Healthy Birds & $-{ }^{c}$ & $-c$ & $27^{\mathrm{a}}\left(14^{\mathrm{b}}\right)$ & $27^{\mathrm{a}}\left(14^{\mathrm{b}}\right)$ \\
\hline Total & & & & $83^{\mathrm{a}}\left(61^{\mathrm{b}}\right)$ \\
\hline
\end{tabular}

${ }^{\text {a }}$ Number of examined samples

${ }^{\mathrm{b}}$ Number of positive samples

${ }^{\mathrm{c}}$ Not subjected for examination

\section{Toxin typing by PCR}


All 61 isolates which had been tentatively identified as C. perfringens from diseased and healthy broiler chickens, were examined for the presence of cpa, cpb, iA, etx, cpb2 and cpe which encode respectively for alpha toxin, beta toxin, iota toxin, epsilon toxin, beta 2 toxin and enterotoxin of $C$. perfringens, by using a multiplex PCR method.

In all $C$. perfringens isolated from diseased and healthy birds harboring the cpa gene of $900 \mathrm{bp}$ fragment (Fig. 3), so all the isolates were confirmed as $C$. perfringens type A. However, the $c p b$, etx, iap and cpe were not detected in any of the examined isolates (Table 2).

A 27/61 (44.3\%) were positive for the presence of $c p b 2$ (b2 toxin) gene of $200 \mathrm{bp}$ fragment (Fig.4). Its presence is particularly high among isolates from affected liver (50\%) (Table 3).

Of the $61 C$. perfringens isolates which had been recovered from diseased and healthy chickens, $37(60.6 \%)$ were netB positive (Fig. 4 and Table 3) 35 out of 47 (74.4\%) were positive for netB gene. Conversely, 2 out of $14(14.3 \%)$ isolates from healthy chickens, were $n e t B$ positive (Table 3 ). 
Table 3: Analysis of virulence factors associated with $C$. perfringens isolates from healthy and diseased broiler chickens

\begin{tabular}{|c|c|c|c|c|c|c|c|c|c|c|}
\hline \multicolumn{3}{|c|}{ Birds Examined } & \multicolumn{7}{|c|}{ C. perfringens toxin-encoding genes } & \multirow[b]{2}{*}{$\begin{array}{l}\text { Isolated } \\
\text { Type }\end{array}$} \\
\hline $\begin{array}{c}\text { Birds } \\
\text { Condition }\end{array}$ & $\begin{array}{l}\text { Sample } \\
\text { Nature }\end{array}$ & $\begin{array}{c}\text { No. of } \\
\text { Positive }\end{array}$ & $\begin{array}{c}c p a \\
(\alpha \text { toxin })\end{array}$ & $\begin{array}{c}c p b \\
(\beta \text { toxin })\end{array}$ & $\begin{array}{c}e t x \\
\text { ( } \varepsilon \text { toxin) }\end{array}$ & $\begin{array}{c}\text { iap } \\
\text { ( } 1 \text { toxin) }\end{array}$ & $\begin{array}{c}c p e \\
\text { (enterotoxin) }\end{array}$ & $\begin{array}{c}c p b 2 \\
\text { (B2 toxin) }\end{array}$ & $\begin{array}{c}\text { net } B \\
\text { (Toxin B) }\end{array}$ & \\
\hline \multirow[t]{2}{*}{ Diseasesd } & Intestine & 41 & + & 0 & 0 & 0 & 0 & $\begin{array}{c}19 \\
(46.3 \%)\end{array}$ & $\begin{array}{c}31 \\
(75.6 \%)\end{array}$ & \multirow{2}{*}{ A } \\
\hline & $\begin{array}{r}\text { Liver (gall } \\
\text { Bladder) }\end{array}$ & 6 & + & 0 & 0 & 0 & 0 & $\begin{array}{c}3 \\
(50 \%)\end{array}$ & $\begin{array}{c}4 \\
(66.6 \%)\end{array}$ & \\
\hline Healthy & $\begin{array}{r}\text { Cloacal } \\
\text { swabs }\end{array}$ & 14 & + & 0 & 0 & 0 & 0 & $\begin{array}{c}5 \\
(35.7 \%)\end{array}$ & $\begin{array}{c}2 \\
(14.3 \%)\end{array}$ & A \\
\hline \multicolumn{2}{|l|}{ Total } & 61 & 61 & 0 & 0 & 0 & 0 & $\begin{array}{c}27 \\
(44.3 \%)\end{array}$ & $\begin{array}{c}37 \\
(60.6 \%)\end{array}$ & \\
\hline
\end{tabular}




\section{DISCUSSION}

Clostridium perfringens is an important pathogen of many animals and can cause a disease known as necrotic enteritis (NE) in avian species. The disease results from extracellular toxin production by the bacterium in the intestinal tract and leads to tissue necrosis and malabsorption and is often fatal (Songer, 1996).

So, in this study we tried to get a broad idea on the situation of $C$. perfringens incidence and types on Assiut broiler chicken farms. Our observations revealed that necrotic enteritis caused 3\% mortality within two days in the broiler chickens of age between three to four weeks old. Broussard et al. (1986) reported that clinical NE cause higher mortality in 2 to 4 weeks old chicken which sometimes exceeds $1 \%$ daily. Severe depression, decreased appetite, diarrhea, reluctance to move and ruffled feathers also reported earlier (Songer, 1996; Das et al., 1997).

In post mortem examination, chickens were found dehydrated and produced fetid odor and had severe lesions and necrosis on the wall of the small intestine and in some cases focal necrosis and hemorrhages on the upper surface of liver (Fig. 1) was also observed. In similar observation, the gross pathological changes were characterized by severe lesions and diffused mucosal necrosis in the small intestine and even in caecum, liver and kidney (Long, 1974; Broussard et al., 1986; Lovland and Kaldhusdal, 2001).

In this study, $C$. perfringens was typically isolated from the duodenal samples of NE-affected birds, whereas isolates from healthy birds could be recovered frequently from cloacal samples only. This has been previously observed in other studies, in which concentrations of C. perfringens are higher in the intestinal tract of NE-affected birds, where the bacteria have proliferated upward into the duodenum and are often associated with coccidial coinfection (Shane et al., 1986).

The patterns of production of the toxins are different, depending on the $C$. perfringens type. Therefore, the patterns have been used to type the bacterium into types A, B, C, D, and E. Some strains of $C$. perfringens may not be able to produce toxin in measurable amounts under laboratory conditions and this causes an obstacle for typing by classical methods. In recent years, PCR techniques have been used to determine C. perfringens toxin types (Songer and Meer, 1996; Baums et al., 2004).

Herein, we describe a simple and rapid multiplex PCR for detection of $C$. perfringens toxin. In the study, all the isolated C. perfringens strains were successfully typed by the multiplex PCR. 
C. perfringens type A, have been isolated from necrotic enteritis cases as well as healthy birds (Fig. 4). In agreement with our study, several studies reported that type A is the predominant type in poultry (Songer 1996; Van Immerseel, et al., 2004). Our Results confirm the most recent results reported from different countries and the data suggest that the role of $C$. perfringens type $\mathrm{C}$ should be revaluated in the pathogenesis of NE.

The pathogenicity of $C$. perfringens is closely related to the production of major lethal toxins (alpha, beta, epsilon, and iota toxins) and other toxins, including enterotoxin (Hatheway, 1990). Recently, others (Keyburn et al., 2008) described NetB, a virulence factor likely involved in the pathogenesis of NE. In a strong support of this, they reported that netB knockout mutants failed to produce $\mathrm{NE}$ in chickens, while such mutants complemented with the wild type netB gene, caused NE.

In a trial to extend the findings of Keyburn et al. (2008) by investigating the occurrence of the net $B$ gene among Egyptian $C$. perfringens isolates and to examine its association with NE. In opposite to the findings of Keyburn et al. (2008), our results revealed that $n e t B$ was found in 35 out of 47 isolates (74.4\%) from diseased chickens, however 2 out of 14 (14.28\%) from healthy chickens (Table ).

Although netB was detected in the majority of isolated strains from diseased broilers, it was found healthy birds as well but in a low percentage. (Table 3). Overall, this study provided a good opportunity to observe the prevalence of the netB gene in a field situation where NEand non-NE-associated isolates were used. The data suggest that this toxin is an important factor in $C$. perfringens infection, facilitating the development of NE. However, our results also show that it is neither a necessary nor a sufficient cause for the disease to occur. As the authors of the netB discovery stated (Keyburn et al., 2008), there may be many other unidentified factors which are important to allow $C$. perfringens type A to compete effectively in the gut and produce tissue damage consistent with NE.

None of the broiler chicken isolates tested in the study were Enterotoxin(cpe)-positive. This result indicates that the enterotoxin is not involved in disease in broiler chickens investigated in the present study. This is in accordance with previous studies, as the cpe gene has been estimated to be present in $<5 \%$ of global $C$. perfringens isolates (Engstrom et al., 2003). 
Beta2 toxin (CPB2) may have a role in the pathogenesis of NE, several studies on the CPB2 toxin strongly suggest an association between this toxin and clostridial gastrointestinal diseases in some domestic animals, including typhlocolitis in horses and necrotic enteritis in piglets (Herholz et al., 1999 and Waters et al., 2003).

Our study surveillance of diseased and healthy chickens revealed the $c p b 2$ gene was found in $44.3 \%$ of isolated $C$. perfringens strains from, but the prevalence varied substantially. Affected liver were yield more $c p b 2$-positive isolates $(50 \%)$. This high rate of occurrence of $c p b 2$ positivity among strains isolated from affected livers is consistent with the contention of other workers, that beta2 plays a role in pathogenesis of C. perfringens-associated hepatitis (Engstrom et al., 2003).

The percentage of $c p b 2$ - positive $C$. perfringens strains in chickens is higher than that reported by previously mentioned by it was reported from Swedish broiler chicken farms (Chalmers et al., 2008) that only 2 of 53 isolates $(4 \%)$ were beta2-toxin gene positive this difference may be owing to geographic location. Furthermore, this is the first report of detection of this gene in $C$. perfringens isolated from other avian species.

In conclusion, the multiplex PCR protocol described by Songer and Bueschel, 1999 was successfully applied in this study and could be used as a new method for typing avian $C$. perfringens isolates that led to avoidance of long time and financial costs if we use the conventional method for typing by toxin neutralization test in mice. The resulting data revealed that the $C$. perfringens isolates included in the study were of toxin type A which throw the light that broiler chickens can act as important source for human infection with $C$. perferingens that lead to food poisoning. Though a good management practices, awareness regarding the disease is in first priority.

We demonstrated for the first time that $C$. perfringens genotypes corresponded to $c p a, c p b$ iap, etx, cpe and $c p b 2$ toxin producing strains from healthy and diseased broiler chickens in Assiut-Egypt. The genotyping results demonstrated that there were differences in the toxin genotype between diseased and healthy broiler chickens that a relatively high percentage of isolates from diseased birds carry the net $B$ and beta 2 toxin genes than from healthy ones.

These findings can be used for epidemiologic studies, prophylaxis programs, and to formulate strategies for correct use of vaccines and suggest a more work needed to elucidate $C$. perfringens pathogenic mechanisms in necrotic enteritis etiology alone and with other predisposing factors like (nutrition, concomitant diseases). 


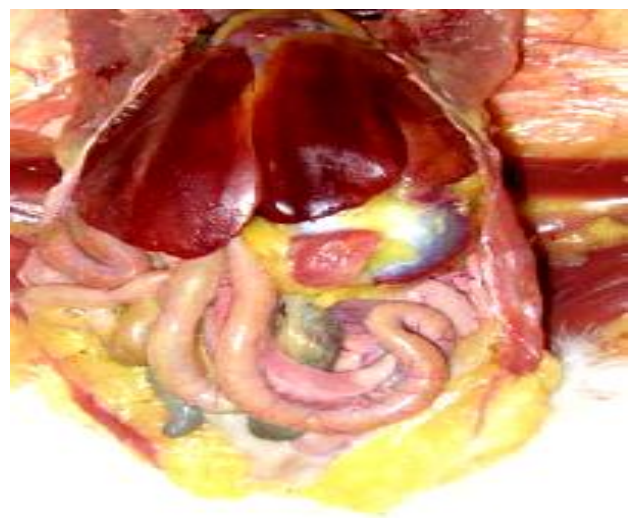

A. Opened Carcass showing yellow mottling and fatty degenrtaion of liver in broiler chicken infected with $C$. perfringens

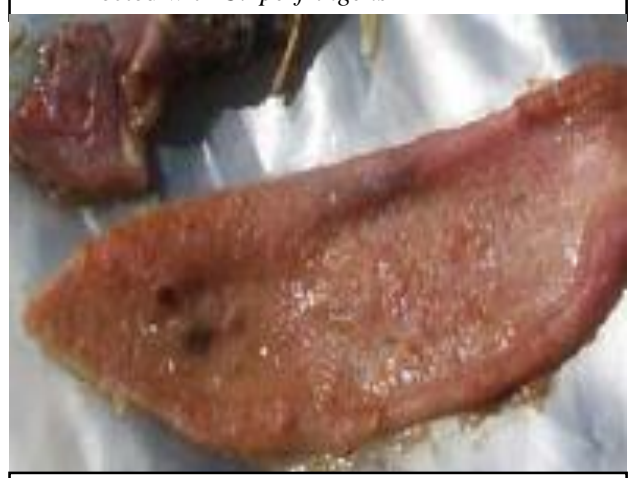

C. Close up view showing thickened and fissured intestinal mucosal membrane like Turkish towel surface

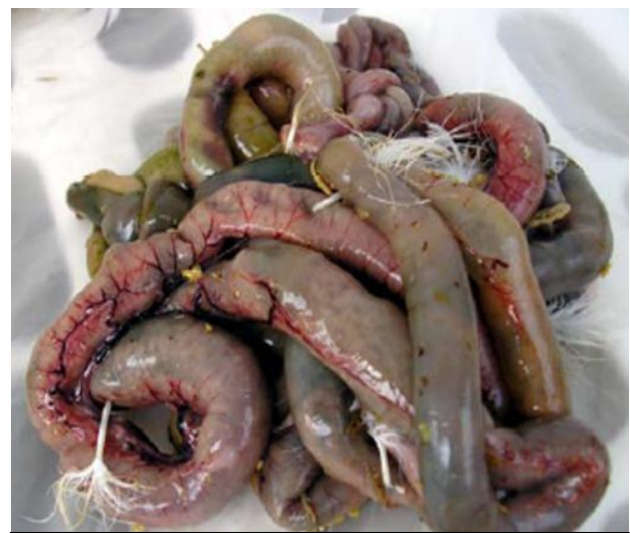

B. Close up view of of small intestine showing ballooning and serosal hemorrhages in birds affected with necrotic enteritis

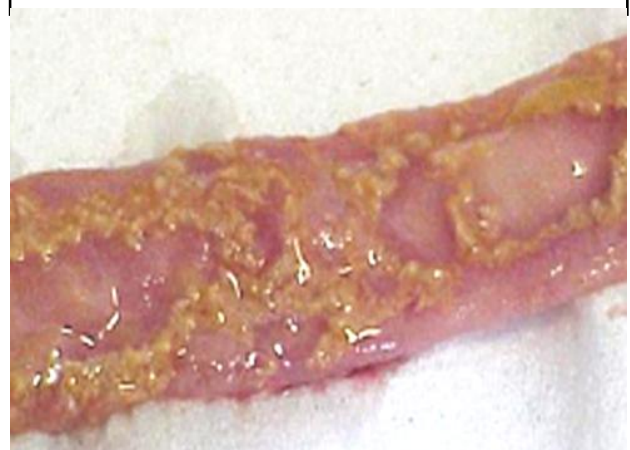

D. Extensive necrosis in the mucosal membrane of small intestine in the affected birds.

Fig. 1 Different postmortem lesion from liver and intestine of the affected birds

Fig. 2 Blood agar cultivated with C. perferingens showing dual hemolysis. The colonies are smooth, round, glistening, surrounded by an inner zone of complete haemolysis and an outer zone of incomplete haemolysis caused by the alpha-toxin 


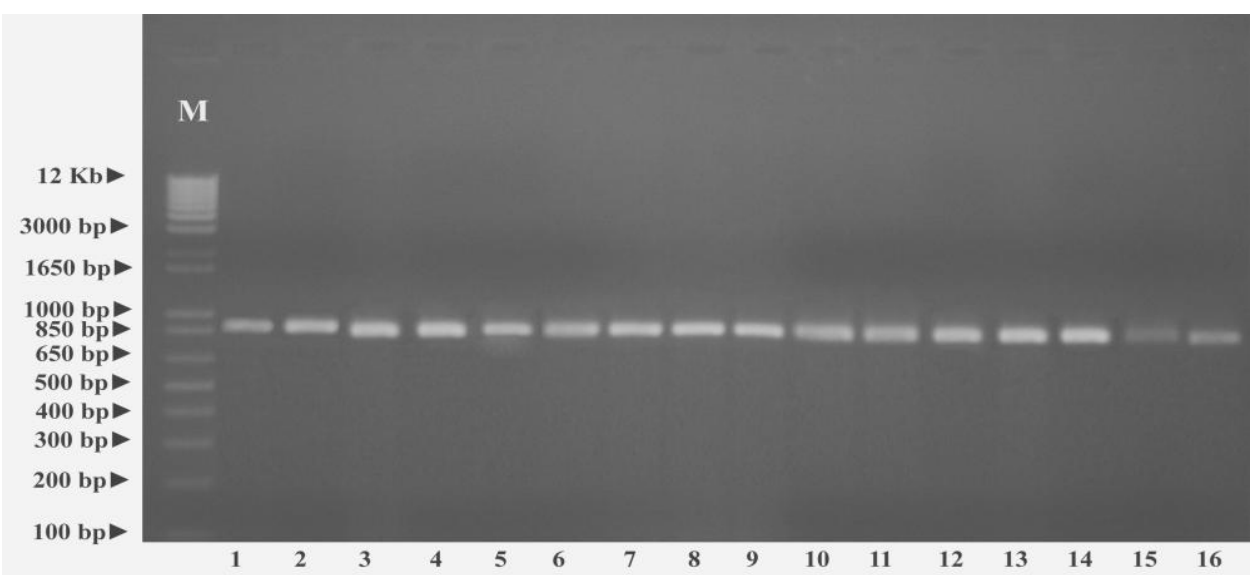

Fig. 3: Amplification of $C$. perfringens toxin genes by the multiplex PCR. Chromosomal DNA was isolated from the bacteria listed in Materials and Methods, and multiplex PCR was performed with template DNA under the conditions described in Materials and Methods. Amplified PCR products were analyzed by electrophoresis on $1.2 \%$ agarose gel. Lane M, DNA size marker (1-kb plus ladder); lane 1-16, C. perfringens type A (alpha toxin gene (cpa) amplification).

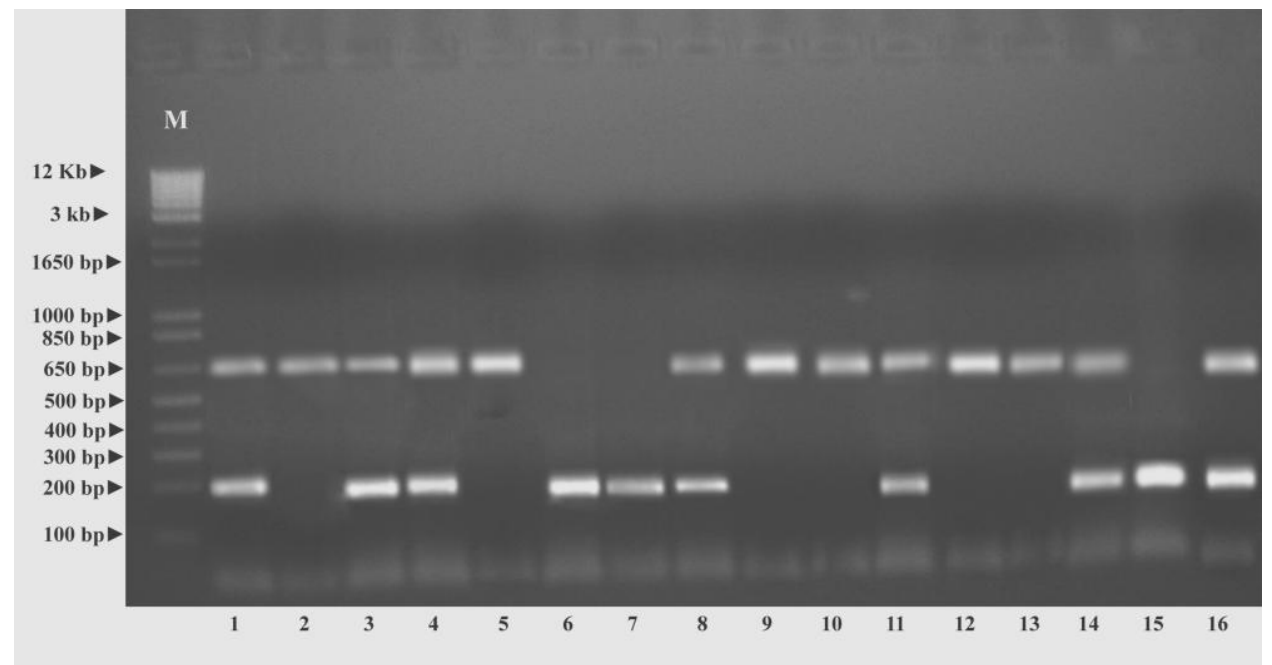

Fig. 4: Multiplex PCR subtyping amplification products for a representative number of $C$. perfringens type A strains. Lane M, 1 $\mathrm{Kb}$ plus DNA ladder; lanes 1, 3-4, 8, 11, 14 and $16 C$. perfringens (net $B^{+}, c p b 2^{+}$type A); lanes 2, 5, 9-10 and 12-13 C. perferingens (net $B^{-}, c p b 2^{+}$type A); Lanes 6-7 (net $B^{+}$and $c p b 2^{-}$type A). 


\section{REFERENCES}

Baums, C.G.; Schotte, U.; Amtsberg, G. and Goethe, R. (2004): Diagnostic multiplex PCR for toxin genotyping of Clostridium perfringens isolates. Veterinary Microbiology, 20: 11-16.

Broussard, C.T.; Hofacre, C.L.; Page, R.K. and Fletcher, O.J. (1986): Necrotic enteritis in cage-reared commercial layer pullets. Avian Dis., 30: 617-619.

Buzby, J.C. and Roberts, T. (1997): Economic costs and trade impacts of microbial foodborne illness. World Health Status Quarterly 50: pp. 57-66.

Chalmers, G.; Martin, S.W.; Hunter, D.B.; Prescott, J.F.; Weber, L.J. and Boerlin, P. (2008): Genetic diversity of Clostridium perfringens isolated from healthy broiler chickens at a commercial farm Veterinary Microbiology 127: 116-127

Copper, K.K.; Trinh, H.T. and Songer, J.G. (2009): Immunization with recombinant alpha toxin partially protects broiler chicks against experimental challenge with Clostridium perfringens. Vet. Microbiol. 133: 92-97.

Dahiya, J.P.; Wilkie, D.C.; Van Kessel, A.G. and Drew, M.D. (2006): Potential strategies for controlling necrotic enteritis in broiler chickens in post-antibiotic era. Animal Feed Science and Technology 129: 60-88.

Das, B.C.; Dutta, G.N.; Devriese, L.A. and Phykan, A. (1997): Necrotic entritis in chickens due to field isolates of Clostridium perfringens type A. Indian J. Vet. Pathol., 21: 27-29.

Eisgruber, H. and Hauner, G. (2001): Minced beef heart associated with a Clostridium perfringens food poisoning in a Munich old people's home. Arch Lebensmittelhyg 52: 63-66.

Engstrom, B.E.; Fermer, C.; Linberga, Saarinen, E.; Baverud, V. and Gunnarsson, A. (2003): Molecular typing of isolates of Clostridium perfringens from healthy and diseased poultry. Vet. Microbiol 94: 225-235.

Ferrarezi, M.C.; Cardoso, T.C. and Dutra, I.C. (2008): Genotyping of Clostridium perfringens isolated from calves with neonatal diarrhea Anaerobe 14 (2008) 328-331.

Fukata, T.; Hadate, Y.; Baba, E.; Uemura, T. and Arakawa, A. (1988): Influence of Clostridium perfringens and its toxin in germ-free chickens. Res. Vet. Sci. 44: 68-70. 
Gholamiandekhordi, A.R.; Ducatelle, R.; Heyndrickx, M.; Haesebrouck, $F$. and Van Immerseel, F. (2006): Molecular and phenotypical characterization of Clostridium perfringens isolates from poultry flocks with different disease status. Vet. Microbiol. 113: 143-152.

Gkiourtzidis, K.; Frey, J.; Bourtzi-Hatzopoulou, E.; Iliadis, N. and Sarris, K. (2001): PCR detection and prevalence of $\alpha-, \beta-, \beta 2$, $\varepsilon-, l^{-}$and enterotoxin genes in Clostridium pefringens isolated from lambs with clostridial dysentery. Veterinary Microbiology, 82: 39-43.

Hatheway, C.L. (1990): Toxigenic clostridia. Clin. Microbiol. Rev. 3: 66-98.

Herholz, C.; Miserez, R.; Nicolet, J.; Frey, J.; Popoff, M.; Gibert, M.; Gerber, H. and Straub, R. (1999): Prevalence of beta2toxigenic Clostridium perfringens in horses with intestinal disorders. J. Clin. Microbiol. 37: 358-361.

Holt, J.G.; Krige, N.R.; Sneeth, P.H.A.; Staley, J.T. and Williams, S.T. (Eds.) (1994): Bergey's Manual of Determinative Bacteriology. 9th (Edn.), Williams and Wilkins, Baltimore, USA, pp: 749-755.

Keyburn, A.L.; Sheedy, S.A.; Ford, M.E.; Williamson, M.M.; Awad, M.M.; Rood, J.I. and Moore, R.J. (2006): Alpha-toxin of Clostridium perfringens is not an essential virulence factor in necrotic enteritis in chickens. Infect. Immun. 74: 6496-6500.

Keyburn, A.L.; Boyce, J.D.; Vaz, P.; Bannam, T.L.; Ford, M.E.; Parker, D.; Di Rubbo, A.; Rood, J.I. and Moore, R.J. (2008): Net B, a new toxin that is associated with avian necrotic enteritis caused by Clostridium perfringens. PLoS Pathog., 4(2): e26.

Long, J.R. (1974): Studies on necrotic enteritis in broiler chickens with emphasis on the role of Clostridium perfringens. Disser. Abs. Int., 35: 2503.

Lovland, A. and Kaldhusdal, M. (2001): Severely impaired production performance in broiler flocks with high incidence of Clostridium perfringens associated hepatitis. Avian Pathol. 30: 73-81.

Lovland, A.; Kaldhusdal, M.; Redhead, K.; Skjerve, E. and Lillehaug, A. (2004): Maternal vaccination against subclinical necrotic enteritis in broilers. Avian Pathol. 33: 81-92. 
McClane, B.A. (2001): Clostridium perfringens. In Food Microbiology: Fundamentals and Frontiers ed. Doyle, M.P., Beuchat, L.R. and Montville, T.J. pp. 351-372. Washington, DC: ASM Press.

McReynolds, J.L.; Byrd, J.A.; Anderson, R.C.; Moore, R.W.; Edrington, T.S.; Genovese, K.J.; Poole, T.L.; Kubena, L.F. and Nisbet, D.J. (2004): Evaluation of immunosuppressants and dietary mechanisms in an experimental disease model for necrotic enteritis. Poult. Sci. 83, 1948-1952.

Parish, W.E. (1961): Necrotic enteritis in the fowl (Gallus gallus domesticus). I. Histopathology of the disease and isolation of a strain of Clostridium welchii. J. Comp. Pathol., 71: 377-393

Petit, L.; Gibert, M. and Popoff, M. (1999): Clostridium perfringens: toxinotype and genotype. Trends Microbiol., 7: 104-10.

Shane, S.M.; Gyimah, J.E.; Harrington, K.S. and Snider III, T.G. (1986): Etiology and pathogenesis of necrotic enteritis. Vet. Res. Commun., 9: 269-287.

Smedley III, J.G.; Fisher, D.J.; Sayeed, S.; Chakrabarti, G. and Mcclane, B.A. (2004): The enteric toxins of Clostridium perfringens. Rev. Physiol. Biochem. Pharmacol., 152: 183-204.

Songer, J.G. (1996): Clostridial enteric diseases of domestic animals. Clin. Microbiol. Rev. 9: 216-234.

Songer, J.G. and Bueschel, D. (1999): Multiplex PCR procedure for genotyping Clostridium perfringens. Available from: http://microvet.arizona.edu/Faculty/songer/ multiplexprocedure.pdf.

Songer, J.G. and Meer, R.M. (1996): Genotyping of Clostridium perfringens by polymerase chain reaction is a useful adjunct to diagnosis of clostridial enteric disease in animals. Anaerobe 2: 197-203.

Van Immerseel, F.; De Buck, J.; Pasmans, F.; Huyghebaert, G.; Haesebrouck, F. and Ducatelle, R. (2004): Clostridium perfringens in poultry: an emerging threat for animal and public health. Avian Pathol 33: 537-549.

Waters, M.; Savoie, A.; Garmory, H.S.; Bueschel, D.; Popoff, M.R.; Songer, J.G.; Titball, R.W.; McClane, B.A. and Sarker, M.R. (2003): Genotyping and phenotyping of beta2-toxigenic C. perfringens fecal isolates associated with gastrointestinal diseases in piglets. J. Clin. Microbiol .41: 3584-3591. 